\title{
PENGARUH MODEL PROBLEM SOLVING MELALUI SIMULASI PhET UNTUK MENINGKATKAN KEMAMPUAN PEMAHAMAN KONSEP SISWA PADA MATERI FLUIDA DINAMIS
}

\author{
Ramadhanty Sembiring ${ }^{1}$, Syarifah Rita Zahara ${ }^{2}$, Nuraini Fatmi ${ }^{2}$ \\ ${ }^{1}$ Mahasiswa dan ${ }^{2}$ Dosen Program Studi Pendidikan Fisika, FKIP Unimal, Aceh Utara \\ Korespondensi: rdhanty01@gmail.com
}

\begin{abstract}
Abstrak: Penelitian ini bertujuan untuk mengetahui apakah ada peningkatan pemahaman konsep siswa kelas XI terhadap pembelajaran fluida dinamis dengan menggunakan model Problem Solving melalui simulasi PhET. Jenis penelitian ini adalah quasi eksperimen dan desain penelitian ini adalah pretest-posttest control design group, dengan kelas XI MIPA 1 sebagai kelas kontrol dan XI MIPA 3 sebagai kelas eksperimen. Instrumen penelitian yang digunakan adalah tes kemampuan pemahaman konsep serta lembar kerja peserta didik. Hasil penelitian diolah dengan menggunakan aplikasi SPSS untuk mengetahui apakah data bersifat normal dan homogen atau tidak, serta untuk mengetahui ada tidaknya peningkatan kemampuan pemahaman konsep siswa setelah diberikan perlakuan. Hasil yang diperoleh adalah rata-rata kemampuan pemahaman konsep siswa kelas XI MIPA 3 lebih tinggi dibandingkan dengan kelas XI MIPA 1. Dengan demikian disimpulkan bahwa penggunaan model Problem Solving melalui simulasi PhET dapat meningkatkan kemampuan pemahaman konsep siswa pada mata pelajaran fisika kelas XI di SMA Negeri 1 Dewantara.
\end{abstract}

Kata Kunci: Pemahaman Konsep, Problem Solving, Simulasi PhET

\begin{abstract}
Abstrack: The purpose of this study was to problem solving with PhET simulation can increase the students comprehension concepts in dynamic fluid. The type of research used is quasi experiment and design of research used is pretest-posttest control design group, with class XI MIPA 1 as control class and XI MIPA 3 as experiment class. When that class have same treatment, and different model. Experiment class used problem solving and control class used conventional model. The result manner by SPSS to know what that the data have the normality and homogeneity and to know that any increase the students comprehension concepts in dynamic fluid. The result shows that average of students comprehension concepts of class XI MIPA 3 higher than class XI MIPA 1. Based onn the text we get conclusion that model prombel solving with PhET simulation can increase the students comprehension concepts in dynamic fluid.
\end{abstract}

Keyword: Comprehension Concepts, Phet Simulation, Problem Solving

\section{PENDAHULUAN}

Humairoh dan Wasis (2015) menyatakan kondisi obyektif pembelajaran di sekolah menunjukkan permasalahan antara lain: (1) Banyak siswa mampu menyajikan tingkat hafalan yang baik terhadap materi pelajaran yang diterimanya, tetapi pada kenyataannya tidak memahaminya; (2) Bagi sebagian siswa, apa yang siswa pelajari tidak bisa dihubungkan dengan bagaimana pengetahuan tersebut akan dimanfaatkan; serta (3) Konsep akademik abstrak yang biasa diajarkan dengan metode ceramah masih dianggap sulit dipahami siswa. Sedangkan menurut Depdiknas (2007) siswa sangat membutuhkan pemahaman konsep yang 
berhubungan dengan aktivitas kehidupan di masyarakat tempat mereka bekerja dan menjalani kehidupan.

Saat ini, proses pembelajaran di sekolah telah diberlakukan kurikulum 2013. Dimana, kurikulum 2013 bertujuan agar peserta didik memiliki kemampuan yang lebih baik dalam melakukan observasi, bertanya, bernalar dan mengkomunikasikannya. Berdasarkan kurikulum 2013 aspek pengetahuan tidak menjadi satu-satunya penentu kelulusan siswa, namun lebih mengutamakan pada pemahaman, skill, dan pendidikan karakter. Dimana siswa dituntut untuk paham atas materi, aktif dalam proses berdiskusi dan presentasi serta memiliki sopan santun dan sikap disiplin yang tinggi. Dalam hal ini pendidikan tidak hanya mengutamakan hasil/produk tetapi proses juga sangat penting dalam membangun pengetahuan siswa.

Kemendikbud (Widiyanto, 2018) menyatakan bahwa tujuan pembelajaran yang terdapat pada kerangka kurikulum 2013 antara lain adalah menguasai konsep dan prinsip serta mempunyai keterampilan untuk mengembangkan pengetahuan, teknologi serta sikap yang diperoleh untuk melanjutkan pendidikan ke jenjang yang lebih tinggi. Berdasarkan tujuan tersebut, maka dapat diketahui bahwa pemahaman konsep pada mata pelajaran fisika sangat penting. Sehingga dalam pengimplementasian kurikulum 2013 harus terdapat lima aktivitas belajar yakni: mengamati, bertanya, melakukan percobaan, melakukan penalaran, dan mengembangkan hasil.

Di sisi lain, seiring dengan kemajuan sisten Teknologi Informasi (TI), dunia pendidikan senantiasa bergerak maju mengikuti perkembangan zaman, khusunya dalam menciptakan media atau metode dengan materi pendidikan berkonten fisika yang semakin menarik, interaktif dan komperensif. Pembelajaran dengan menggunakan komputer dikenal dengan konsep pembelajaran berbasis komputer (Komputer-assisted intruction) atau CAI.

Pembelajaran berbasis komputer berarti proses pembelajaran yang menggunakan alat bantu dan sumber belajar dengan sistem komputer dalam mencapai tujuan pembelajaran. Penggunaan teknologi informasi dan komunikasi menjadi sebuah cara yang efektif dan efisien dalam menyampaikan informasi. Menurut Markos (2012) teknologi informasi dan komunikasi memiliki potensi besar untuk meningkatkan kualitas pembelajaran, khususnya dalam menampilkan fenomena fisika. Menerapkan teknologi ke dalam pembelajaran fisika maka, siswa akan lebih antusias dalam mengikuti pembelajaran karena, seperti yang kita ketahui siswa sekarang jauh lebih tertarik dengan teknologi dibandingkan dengan ilmu pengetahuan terlebih lagi ilmu fisika.

The PhET Team (2011) mengatakan, Simulasi PhET menggunakan gambar bergerak (animasi), bersifat interaktif dan dibuat layaknya permainan dimana siswa dapat belajar dengan bereksplorasi. Sehingga, dengan kata lain media PhET dapat dimanfaatkan untuk pembelajaran fisika. Susilo (2010) menyatakan bahwa selain guru, bahan ajar, dan metode, keberhasilan pembelajaran juga dipengaruhi oleh media yang digunakan. Selain itu Musfiqon (Firdaus, dkk, 2013) menyatakan penggunaan media yang relevan mampu menjadikan proses pembelajaran berlangsung efektif dan efisien.

Berdasarkan observasi berupa tes soal materi fluida dinamis kepada siswa/i di SMA Negeri 1 Dewantara, masih banyak siswa yang masih kurang memahami materi fluida dinamis. Hal ini dikarenakan siswa sulit untuk membedakan persamaan-persamaan yang akan digunakan. Dari kenyataan tersebut maka, dapat penulis artikan bahwasanya materi fluida dinamis sangat sulit untuk dipahami dan diingat konsepnya.

\section{METODE}


Penelitian ini merupakan penelitian kuantitatif dengan jenis penelitian quasi eksperimen, yaitu penelitian yang bertujuan untuk mengetahui ada tidaknya pengaruh atau akibat dari sesuatu yang ditimbulkan pada subjek yaitu siswa. Sampel yang digunakan pada penelitian ini terbagi atas dua kelas, yaitu kelas eksperimen dan kelas kontrol. Kelas eksperimen akan diberikan perlakukan pembelajaran Problem Solving melalui simulasi PhET, sedangkan kelas kontrol diberikan perlakuan pembelajaran konvensional.

Desain penelitian yang digunakan merupakan pretest-posttest control design group. Desain ini merupakan desain penelitian yang paling efektif dalam penelitian untuk mengetahui suatu sebab akibat. Desain tidak hanya mengukur kemampuan siswa setelah diberikan perlakuan, tetapi juga untuk mengetahui perubahan kemampuan siswa. Hal ini dikarenakan pada desain ini digunakan pretest untuk mengetahui kemampuan dasar siswa dan posttest untuk mengetahui kemampuan akhir siswa.

Tabel 1. Desain Penelitian

\begin{tabular}{|c|c|c|c|}
\hline Kelas & Pretest & Perlakuan & Posttest \\
\hline Eksperimen & $O_{1}$ & $X$ & $O_{2}$ \\
\hline Kontrol & $O_{1}$ & $Y$ & $O_{2}$ \\
\hline
\end{tabular}

Keterangan : $\mathrm{O}_{1}=$ Pretest

$\mathrm{O}_{2}=$ Posttest

$\mathrm{X}=$ Model pembelajaran problem solving melalui simulasi PhET

$\mathrm{Y}=$ Model pembelajaran konvensional

Sesuai dengan jenis penelitian yang dilakukan, yaitu penelitian quasi eksperimen, maka penelitian akan dilakukan berdasarkan ketentuan berikut:

a) Soal pretest dan posttest untuk setiap kelas adalah sama

b) Materi yang diberikan untuk setiap kelas adalah sama

c) Alokasi waktu penyampaian materi untuk kedua kelas adalah sama

d) Guru yang menyampaikan materi pembelajaran untuk kedua kelas adalah sama, yaitu peneliti sendiri

e) Perbedaan perlakuan hanya terletak pada model yang digunakan pada saat menyampaikan materi pembelajaran

\section{HASIL DAN PEMBAHASAN}

Hasil

Hasil pemahaman konsep siswa pada materi fluida dinamis diperoleh dari hasil uji soal pretest dan posttest pada masing-masing kelas. Adapun hasil untuk masing-masing kelas adalah sebagai berikut:

1) Kelas Eksperimen

Hasil pretes dan posttest kelas eksperimen dapat dilihat pada tabel 2 sebagai berikut:

Tabel 2. Hasil Kelas Eksperimen

\begin{tabular}{|c|c|c|c|c|c|c|}
\hline & Nilai & $N$ & $X_{\min }$ & $X_{\text {maks }}$ & $\bar{X}$ & $S$ \\
\hline Pretest & 1628 & 25 & 36 & 88 & 65,12 & 13,68 \\
\hline Posttest & 2062 & 25 & 66 & 95 & 82,48 & 5,17 \\
\hline N-Gain & 434 & 25 & 4 & 36 & 17,36 & 85,65 \\
\hline \multicolumn{7}{|c|}{ skor maksimum ideal adalah 100} \\
\hline
\end{tabular}


Berdasarkan tabel 3 dapat diketahui bahwa terjadi peningkatan pemahaman konsep siswa pada kelas eksperimen. Hal ini dapat dilihat melalui nilai rata-rata yang diperoleh siswa pada saat pretest dan posttest.

2) Kelas Kontrol

Hasil pretes dan posttest kelas eksperimen dapat dilihat pada tabel 3 sebagai berikut:

Tabel 3. Hasil Kelas Kontrol

\begin{tabular}{|c|c|c|c|c|c|c|}
\hline & Nilai & $N$ & $X_{\min }$ & $X_{\text {maks }}$ & $\bar{X}$ & $S$ \\
\hline Pretest & 1432 & 23 & 36 & 88 & 62,26 & 17,00 \\
\hline Posttest & 1698 & 23 & 57 & 90 & 73,83 & 10,62 \\
\hline N-Gain & 266 & 23 & 1 & 30 & 11,57 & 7,95 \\
\hline \multicolumn{7}{|c|}{ skor maksimum ideal adalah 100} \\
\hline
\end{tabular}

Berdasarkan tabel 3 dapat diketahui bahwa terjadi peningkatan pemahaman konsep siswa pada kelas kontrol. Hal ini dapat dilihat melalui nilai rata-rata yang diperoleh siswa pada saat pretest dan posttest.

\section{Pembahasan}

Berdasarkan hasil uji pretest dan posttest pada kelas eksperimen dan kelas kontrol dapat diketahui bahwa peningkatan rata-rata hasil pemahaman konsep siswa terhadap materi fluida dinamis bernilai lebih tinggi untuk kelas eksperimen dari pada kelas kontrol. Hal ini menunjukkan bahwa terdapat pengaruh terhadap perlakuan yang diberikan pada masingmasing kelas. Kelas eksperimen memiliki peningkatan rata-rata hasil pemahaman konsep siswa lebih tinggi dikarenakan pada proses pembelajaran menggunakan model problem solving melalui simulasi PhET. Sedangkan pada kelas kontrol memiliki peningkatan rata-rata hasil pemahaman konsep siswa lebih rendah dari kelas eksperimen dikarenakan pada proses pembelajaran menggunakan model konvensional.

Penggunaan model problem solving melalui simulasi PhET tidak hanya berdampak terhadap peningkatan pemahaman konsep siswa. Tetapi juga berdampak terhadap proses pembelajaran yang berlangsung. Pada proses pembelajaran menggunakan model problem solving melalui simulasi PhET kondisi ruangan lebih aktif. Selain itu siswa tidak merasa tertekan pada saat berlangsungnya proses pembelajaran. Siswa juga lebih antusias terhadap pembelajaran dan siswa mengaku lebih mudah memahami konsep fisika terutama pada materi fluida dinamis pada saat proses pembelajaran berlangsung dengan menggunakan model problem solving melalui simulasi PhET dikarenakan siswa melihat langsung kondisi atau permaslahan yang akan diselesaikan melalui simulasi PhET.

Sedangkan proses pembelajaran pada kelas kontrol yang menggunakan model konvensional cenderung tidak aktif. Selain itu siswa merasa tertekan dan terbebani dikarenakan pembelajaran hanya terfokus pada papan tulis tanpa ada media pendukung lainnya. Siswa juga merasa sulit untuk memahami pelajaran fisika terutama pada materi fluida dinamis. Hal ini dikarenakan siswa harus menggunakan imajinasii atau berkhayal untuk menyelasaikan suatu permasalahan atupun untuk memahami suatu konsep.

Pada saat uji pretest diperoleh rata-rata hasil pemahaman konsep siswa kelas eksperimen sebesar 65,12 dan rata-rata hasil pemahaman konsep siswa pada saat uji posttest kelas eksperimen sebesar 85,48. Dengan demikian dapat dilihat terjadi peningkatan rata-rata pemahaman konsep siswa kelas eksperimen sebesar 17,36. sedangkan pada kelas kontrol diperoleh rata-rata hasil pemahaman konsep siswa pada saat pretest sebesar 62,26 dan ratarata hasil pemahaman konsep siswa pada saat posttest sebesar 73,83 . Dengan demikian peningkatan rata-rata pemahaman konsep siswa pada kelas kontrol sebesar 11.57. 
Adapun peningkatan pemahaman konsep siswa yang menggunakan model problem solving senilai 49\%. Mariati (2012) juga memperoleh hal yang sama, $N$-Gain pemahaman konsep pada materi kinematika partikel yaitu 61\%. Adapun perolehan $N$-Gain peneliti lebih rendah dibandingkan dengan penelitian lain dikarenakan penelti hanya terfokus kepada model problem solving tanpa memperhatikan faktor pendukung dalam melaksanakan model problem solving.

\section{PENUTUP}

Berdasarkan data penelitian yang diperoleh maka dapat disimpulkan ada pengaruh penggunaan model pembelajaran problem solving melalui simulasi PhET terhadap pemahaman konsep siswa pada materi fluida dinamis kelas XI SMA Negeri 1 Dewantara. Dengan kata lain, pemahaman konsep siswa dapat meningkat jika pembelajaran berlangsung dengan menggunakan model problem solving melalui simulasi PhET dibandingkan dengan model konvensional.

\section{DAFTAR PUSTAKA}

Depdiknas. (2010). Model-Model Pembelajaran. Jakarta: Depdiknas.

Firdaus, dkk. (2013). Peran program PhET Dalam Pembelajaran Fisika. Yogyakarta.

Humairoh. F, Wasis. (2015). Pengembangan E-Book Interaktif Berbasis Salingtemas (Sains, Lingkungan, Teknologi, Masyarakat) Pda Materi Fluidaa Dinamis Untuk Meningkatkan Pemahaman Konsep Siswa dan Penerapannya. Jurnal Inovasi Pendidikan Fisika (JIPF) 4(2): 69-75.

Mariati, P. S. (2012). Pengembangan Model Pembelajaran Fisika Berbasis Problem Solving Untuk Meningkatkan Kemampuan Metakognisi dan Pemahaman Konsep Mahasiswa. Jurnal Pendidikan Fisika Indonesia, 8 (2012): 152-160.

Markos, S. S. (2012). Penggunaan teknologi informasi dan komunikasi dalam pembelajaran fisika. Palembang. Prosiding Seminar Nasional Fisika. Program Studi Pendidikan Fisika dan Program Magister Teknologi Pendidikan, Fakultas Keguruan dan Ilmu Pendidikan. Universitas Sriwijaya.

Sugiyono. (2016). Metode Penelitian Kuantitatif, Kualitatis, Dan R\&D. Bandung: Alfabeta.

Susilo, M. (2010). Menjadi Guru Profesianal, Siapa Takut?. Yogyakarta: Lentera Pustaka.

The PhET Team. (2011). PhET (Intective Simulations). http://phet.colorado.edu/in/. Diunduh tanggal 11 September 2018.

Widiyanto, A. Sujarwanto, E. Prihaningtiyas, S. (2018). Analisis Pemahaman Konsep Peserta Didik Dengan Instrumen Four Tier Diagnostic Test Pada Materi Gelombang Mekanik. Seminar Nasional Multidisiplin. 